\title{
Komodifikasi Agama: Studi Analisis terhadap Tampilan Agama di Media Televisi
}

\author{
Ari Wibowo \\ Fakultas Dakwah dan Komunikasi Islam \\ IAIN Syaikh Abdurrahman Siddik Bangka Belitung, Indonesia \\ ari@iainsasbabel.ac.id
}

\begin{abstract}
The appearance of religion in television media tends to be colored by the principles of commercialization and capitalism. The religious program is presented not only has an impact on the exchange of values (change values) but also on the exchange of money (change money). With a descriptive qualitative approach, this article seeks to explain the appearance of religion in several religious programs broadcast by several Indonesian television media. The observation method was used to identify several religious programs and controversial dramas, such as the drama "Bubur Naik Pilgrimage" on RCTI, Haji Medit drama on SCTV, and drama "Azab" on Indosiar. The result is that religious programs and dramas where shown on television are commercialized to attract the attention of the audience and increase ratings. So this is what led to the commodification of religion in several television media in Indonesia. The commodification of religion in Indonesian television media appeared during the month of Ramadan.

Tampilan agama di media televisi cenderung diwarnai dengan prinsip komersialisasi dan kapitalis. Program acara relegi yang disajikan tidak hanya berdampak pada pertukaran nilai (change values) tetapi juga pada pertukaran uang (change money). Dengan pendekatan kualitatif deskriptif, artikel ini berupaya menjelaskan dan memaparkan tampilan agama dalam beberapa program religi yang siarkan oleh beberapa media televisi indonesia. Metode observasi digunakan untuk mengidentifikasi beberapa program religi dan sinetron yang kontroversial, seperti sinetron "Tukang Bubur Naik Haji" di RCTI, sinetron Haji Medit di SCTV, dan sinetron "Azab” di Indosiar. Hasilnya bahwa program acara religi dan sinetron yang ditampilkan di televisi dikomersialisasi untuk menarik perhatian khalayak dan meningkatkan rating. Sehingga inilah yang menyebabkan terjadinya komodifikasi agama di beberapa media televisi di Indonesia. Komodifikasi agama di media televisi Indonesia nampak pada saat bulan Ramadan.
\end{abstract}

Keywords: Religion, Media, Commodification 


\section{A. Pendahuluan}

Keberadaan media massa televisi di era virtual saat ini masih menarik perhatian masyarakat, karena televisi bukan saja sebagai media hiburan tapi juga memiliki fungsi lain sebagai kontrol sosial, pendidikan, dan mampu menyampaikan informasi secara cepat. Selain itu, televisi juga merupakan salah satu media komunikasi yang memegang peranan penting dalam kehidupan manusia dewasa ini dan terkait dengan realita, televisi merupakan sarana yang mudah, murah, dan efisien dalam memenuhi kebutuhan manusia. Keefisienan dari televisi dapat dilihat ketika pemirsanya dihadirkan dengan acara-acara yang menarik, dan acara itu dapat dinikmati dengan melakukan aktifitas lain sehingga tidak menyita waktu.

Oleh karena itu, pada saat ini media televisi telah menjadi media komunikasi dalam beragama, sehingga semua pesan-pesan dan ajaran agama dapat ditampilkan melalui media televisi. Hal ini dapat terlihat dari peningkatan dan pengembangan dakwah Islam yang telah masuk ke dalam ruang-ruang televisi sebagai bentuk tampilan agama di media. Misalnya, paket siraman rohani Islam setiap menjelang subuh maupun sesudah shalat Subuh di semua televisi swasta, membuktikan niat baik televisi dalam membina kerohanian Islam. Termasuk hampir setiap televisi swasta memberikan informasi jadwal shalat dengan menayangkan teks berjalan, ini juga membuktikan kepedulian televisi terhadap kepentingan umat Islam.

Selain itu, bermunculan juga sinetron-sinetron islami, talk show islami, dan berbagai program lainnya. Apalagi konten-konten islami semakin bermunculan saat menjelang bulan Ramadan. Namun di balik muatan sisi positif dari media televisi, tentu ada muatan negatif yang dihasilkannya. Hal ini seperti apa yang diungkapkan Mar'at yang dikutip oleh Onong Uchjana Effendy bahwa, pada umumnya televisi mempengaruhi sikap pandangan, persepsi, dan perasaan penonton. ${ }^{1}$

\footnotetext{
${ }^{1}$ Kemunculan beragam program acara yang bernuansa islami bersifat musiman. Program ini kerap muncul pada saat bulan ramadaan dan terkadang muncul pada saat Perayaan Hari Besar Islam (PHBI). Kehadiran televisi sebagai media audio-visual memiliki karakter yang sangat berbeda dengan radio. Televisi memiliki dampak atau efek media yang jauh lebih besar dibandingkan radio. Liihat Onong Uchjana Effendy, Ilmu, Teori, dan Falsafah Komunikasi, (Bandung : Cipta Aditya Bakti 2002), hal. 192
} 
Melihat adanya kecenderungan keterpengaruhan para penonton oleh penayangan acara televisi, maka secara sadar atau tidak penonton akan melihat apa yang dilihat di televisi bahkan meniru apa yang ia lihat di televisi. Senada dengan apa yang disampaikan oleh Ashadi Sireger bahwa diakui atau tidak, orang tua, pemuka agama, dan guru telah kehilangan peranannya secara drastis. Sudah tidak asing lagi televisi dijuluki sebagai surrogate parent (orang tua pengganti), substitute teacher (guru pengganti). ${ }^{2}$ Ditambah lagi dengan persoalan kapitalisme media, karena media televisi tidak bisa dilepaskan dari aspek sistem komersial. Sebagian besar televisi komersial lebih banyak menawarkan program-program hiburan dari pada menggagas sebuah acara yang bisa memberikan informasi dan edukasi yang sehat untuk pencerahan kehidupan masyarakat.

David Morley juga menambahkan bahwa, dewasa ini penonjolan orientasi kapitalis telah menjadi ideologi yang mendasari semua program dalam televisi komersial. $^{3}$ Demi mencari keuntungan dan kreatifitas bisnis itulah akhirnya para kreator industri televisi selalu berusaha membuka peluang-peluang dengan membuat program-program baru yang diprediksikan diminati konsumen. Hal tersebut dapat dilihat dari beberapa tayangan sinetron yang bernuansa Islam, seperti, dalam sinetron “Tukang Bubur Naik Haji” yang telah mencapai lebih dari 500 episode itu. Di sinetron ini muncul karakter Haji Muhidin, yang digambarkan sebagai sosok bapak haji yang jelek, pelit, suka ngomongin orang, suka su'udzhon, dan ribut melulu dengan sesama muslim. Dalam sinetron Haji Medit yang ditayangkan SCTV, sosok haji yang diperankan Jarwo Kuat itu juga ditampilkan sebagai seorang haji yang buruk. Namun di mata produser, sutradara, dan penulis cerita sepertinya punya logika sendiri. Tidak

\footnotetext{
${ }^{2}$ Televisi bukan lagi menjadi tontonan tetapi juga menjadi tuntunan. Pola konsumsi masyarakat terhadap media televisi juga sangat tinggi. Dalam catatan Nielsen Indonesia pernah mencapai puncak tertinggi konsumsi khalayak televisi di Indonesia sebesar $95 \%$ pada tahun 2014 dan rata-rata waktu menonton selama 4,5 jam perhari. Lihat Ashadi Sireger, Menyingkap Media Penyiaran: Membaca Televisi Melihat Radio, (Yogyakarta : LP3Y, 2001), hal. 27

${ }^{3}$ Pengaruh owner atau gate keeper dalam industri media memiliki dominasi yang kuat dalam pengambilan kebijakan organisasi. Inilah yang menyebabkan adanya propaganda dan berkembangnya prinsip kapitalisme dalam industri media tersebut. Lihat David Morley, Television, Audiences and Cultural Studies, (New York: Routlegde, 1992)
} 
jarang guna menarik dan menuai simpati pemirsa, sang tokoh dibuat unik, nyentrik, dan terkadang kontroversial.

Berangkat dari hal di atas, maka tulisan ini berupaya untuk menemukan solusi yang konstrukif dalam mengatasi hal tersebut, sehingga program televisi yang bernuansa Islam tidak mesti harus dihentikan atau mendapat kecaman, tetapi tetap ditampilkan dengan konten (isi) tayangan yang benar sesuai dengan ajaran agama, melalui pengembangan konsep dan teori dakwah.

\section{B. Potret Sajian Agama dan Program Dakwah di Televisi}

Kehadiran dakwah di media televisi berfokus pada bagaimana sajian agama dikemas dan dihadirkan berbeda. Hal ini karena beragamnya penonton sehingga kemasan yang berbeda akan membawa daya tarik tersendiri bagi pemirsa untuk menonton acara dakwah. Dakwah di media massa dikemas dengan berbagai sajian, di antaranya: sinetron religi, kompetisi pencarian da'i yang disajikan di media, dan acara dakwah yang dihadirkan setiap hari di stasiun TV swasta. Sinetron religi yang muncul di media ditujukan sebagai bentuk dakwah di media. Sinetron religi diawali dengan sinetron Rahasi Ilahi di TPI (sebelum berubah menjadi MNC TV) dan sinetron Hidayah di Indosiar. Setelah sinetron tersebut muncul, maka mulai juga bermunculan sinetron dengan kemasan lebih menarik, dan lebih banyak melibatkan artis-artis terkenal serta memiliki sisi cerita yang berbeda. Beberapa contohnya adalah: Ketika Cinta Bertasbih, Para Pencari Tuhan, Islam KTP, Ranum, Munajah Cinta, Pesantren \& Rock And Roll, Surga Untukmu, Kupinang Kau dengan Bismillah, Sampeyan Muslim?, dan sebagainya. Selain sinetron religi, bermunculan juga film layar lebar bertajuk religi, diantaranya: Ayat-Ayat Cinta, Ketika Cinta Bertasbih, Wanita Berkalung Sorban, Di balik Lindungan Ka'bah, dan lain sebagaianya.

Selain sinetron religi, kemasan dakwah berupa ceramah agama di media televisi juga mulai mendapatkan perhatian ketika muncul (alm) Zainudin MZ, beliau membawa perubahan metode berdakwah dari konvensional menjadi dakwah kontemporer. Dakwah yang dilakukan Zainudin MZ direkam menggunakan pita kaset sehingga diputar 
berulangkali di radio dan didengar oleh jutaan umat. Hal ini menyebabkan Zainudin MZ mendapatkan julukan "da'i sejuta umat".

Setiap stasiun televisi swasta di Indonesia memiliki acara dakwah Islam, dan beberapa stasiun televisi menyiarkan acara dakwah hanya pada hari tertentu. Seperti; ANTV memiliki 3 program acara dakwah, yaitu: "Hati ke Hati bersama Mama Dedeh" (setiap hari Senin-Jumat pukul 06.30-07.30 WIB), "Wisata Hati” (setiap hari pukul 05.00- 05.30 WIB), dan "Chating bersama YM" (setiap hari Kamis-Jumat pukul 21.3022.30 WIB). Program Acara "Hati ke Hati bersama Mama Dedeh" membahas permasalahan keluarga dalam kehidupan sehari-hari yang dilihat dari kacamata Islam. Program acara ini dipandu oleh Abdel sebagai host dan Mamah Dedeh sebagai pembicara atau pengisi acara.

INDOSIAR memiliki 3 program acara dakwah, yaitu: "Mamah \& Aa" (setiap hari Senin-Kamis pukul 05.00-06.00 WIB), "Obat Hati” (setiap hari Jumat-Sabtu pukul 05.00-06.00 WIB), dan "Pintu-Pintu Syurga" (setiap hari Minggu pukul 05.00-06.00 WIB). "Mamah \& Aa" merupakan program acara religi yang membahas permasalahan rumah tangga yang berkaitan dengan kehidupan sehari-hari. Acara ini dikemas dengan Mama Dedeh sebagai narasumber, Abdel sebagai host, dan dihadiri oleh ibu-ibu jamaah pengajian. Mamah Dedeh menyampaikan ceramah dengan bahasa yang tegas dan lugas. Mamah Dedeh juga menjawab pertanyaan yang dikirim oleh pemirsa melalui email dan telepon serta para jamaah yang hadir juga diberikan kesempatan untuk bertanya.

TRANS TV memiliki 2 program acara dakwah, yaitu "Islam Itu Indah" (setiap hari pukul 05.30-06.30 WIB) dan "Mozaik Islam" (setiap hari Minggu pukul 07.3008.00 WIB). "Islam Itu Indah" merupakan acara dakwah yang mengundang dua bintang tamu dan dihadiri oleh jamaah pengajian dari beberapa kota. Jamaah yang hadir tidak hanya ibu- ibu, namun juga ada jamaah laki-laki, bahkan anak-anak. Tema yang disajikan dalam setiap minggunya bervariasi dan acara ini memiliki tema weekend yang menyajikan perjalanan ke kota-kota di Indonesia. "Mozaik Islam" merupakan acara religi yang edukatif dan informatif. "Mozaik Islam" menyajikan beragam informasi penting dan menarik dari seluruh dunia yang berkaitan dengan agama Islam. Misalkan 
bagaimana pandangan Islam mengenai tatto, operasi plastik, dan hal lain yang berkaitan dengan permasalahan sehari-hari yang bersifat kekinian.

MNC TV memiliki 4 program acara dakwah yang berkala disiarkan setiap minggunya. "Siraman Qolbu" dan "Majelis Sakinah" (setiap hari Selasa-Kamis dan Sabtu pukul 04.30-05.30 WIB) merupakan acara religi yang menyajikan tausiyah yang disajikan dengan hanya menghadirkan host dan narasumber tanpa adanya jamaah di studio. Tema yang disajikan pun cenderung serius dan lebih dalam menelaah makna ayat yang ada dalam Al-Quran dan Hadits. "Taman Hati” (setiap hari Jumat pukul 04.00- 05.30 WIB) merupakan acara religi yang berisi tausiyah dari Ustazah Ummi Qurrota sebagai nara sumber dan sebagai host. Pembahasan dalam setiap episodenya adalah mengenai permasalahan kehidupan sehari-hari dilihat dari sudut pandang agama Islam. Ustazah Ummi Qurrota memberikan tausiyah dengan suara yang lantang dan dengan bahasa yang cenderung blak-blakan. Dalam setiap tausiyahnya selalu mengadakan interaksi dengan host maupun jamaah yang hadir dengan humornya yang khas.

RCTI hanya memiliki 1 program acara dakwah yang disiarkan setiap hari, yaitu: “Assalamualaikum Ustaz” (setiap hari pukul 04.00-04.30 WIB). Acara ini berlangsung di studio dengan posisi ibu-ibu pengajian melingkar dan ditengahnya ada ustaz yang menjadi narasumber, dan Ali Zaenal sebagai moderator atau host. Acara ini memiliki beberapa mubaligh, yaitu: Ustaz Hidayat Nurwahid, Ahmad Al Habsyi, dan Ustazah Munifat. Beberapa mubaligh tersebut dihadirkan secara bergantian dalam beberapa episode. Acara ini menyajikan berbagai tema dengan tidak terlalu serius karena diselingi humor. Berbagai hal yang berkaitan langsung dengan ayat Al-Qur'an dibahas dengan detail dan ibu-ibu jamaah pengajian diberi kesempatan untuk bertanya.

SCTV memiliki 1 program acara dakwah yang disiarkan setiap hari. "Kata Ustaz Solmed" (setiap hari pukul 04.00-04.30 WIB) merupakan acara religi islami yang menyajikan beragam tausiyah dari Ustaz Sholeh Mahmoed (Ustaz Solmed) membahas berbagai pengetahuan dan wawasan tentang Islam yang disampaikan secara lugas dan jelas. "Kata Ustaz Solmed" menghadirkan bintang tamu yang akan menceritakan 
problematika yang sedang dihadapinya dan Ustaz Solmed akan memberikan tausiyahtausiyahnya sebagai bentuk pencerahan dari problematika tersebut.

GLOBAL TV memiliki program acara dakwah yang berkala disiarkan setiap minggunya. "Alhamdulillah Akhirnya Aku Tahu" (setiap hari Senin, Selasa dan Jumat pukul 03.30-04.00 WIB) merupakan salah satu acara religi yang dikemas dengan sinetron atau memiliki alur cerita dari kejadian tertentu. Acara ini menghadirkan artisartis untuk memerankan peran berdasar tema yang dibahas pada episode tersebut. Acara ini disajikan dengan dialog-dialog antara pemain yang memerankan dan Ustaz hadir sebagai pemberi solusi atas persoalan yang dihadapi. Ustaz yang menjadi narasumber acara ini adalah Ustaz Mirza Zacky dan artis pendamping yang selalu ada adalah Irfan Hakim.

TV ONE memiliki 2 program acara dakwah yang berkala disiarkan setiap minggunya, yaitu: Titian Qolbu, Jejak Islam, dan Damai Indonesiaku. "Titian Qolbu" (setiap hari pukul 03.30-04.30 WIB) merupakan acara religi yang membahas mengenai hal yang berkaitan dengan kehidupan sesuai daengan ajaran Islam. Tema yang disajikan dalam setiap harinya berbeda. Acara ini berlangsung di masjid dengan ustaz yang merupakan habib ternama dan dipandu oleh Ali Zaenal sebagai host. Tema disampaikan dengan keseriusan dan kekhusyukan dari narasumber dan di akhir acara di tutup dengan doa bersama. "Jejak Islam" (setiap hari Sabtu pukul 15.00-16.00 WIB) menyajikan tempat- tempat bersejarah dalam penyiaran agama Islam beserta penjelasan mengenai tempat tersebut, dipandu oleh host. "Damai Indonesiaku" (setiap hari Sabtu dan Minggu pukul 13.00-15.00 WIB) merupakan tausiyah akbar yang berlangsung di masjid-masjid di seluruh Indonesia. Acara ini disajikan live yang menghadirkan jamaah yang berasal dari daerah sekitar masjid tersebut. Acara ini menghadirkan dakwah yang cenderung sama dengan dakwah sebelum muncul di media massa, yaitu hadir di satu lokasi dan mengundang warga sekitar untuk hadir secara bersama-sama. Acara ini selalu dihadiri oleh ratusan jamaah yang berkumpul dipandu dengan berbagai ulama ternama dengan penuh kekhusyukan tanpa diselingi humor yang mengundang tawa jamaah. 
TRANS 7 memiliki memiliki 3 program acara dakwah, yaitu: "Khazanah", dan "Khalifah" yang secara berkala disiarkan setiap minggunya. "Khazanah" (setiap hari Senin-Jumat pukul 05.00-05.30 WIB) merupakan program acara ensiklopedi Islam yang edukatif, menyajikan informasi penting dan menarik dari seluruh dunia berkaitan dengan dunia Islam. Acara ini mengungkapkan perkembangan, sejarah dan berbagai hal menarik dalam dunia Islam.

Program Acara "Khalifah" (setiap hari Jumat dan Sabtu pukul 05.00-05.30 WIB) menyajikan tentang perkembangan dan penyebaran agama Islam yang melibatkan peran para sahabat, tabi'in (murid sahabat), dan tabi'in tabi'in (murid tabi'in). Para khalifah merupakan pihak yang memiliki andil besar dalam mengokohkan pondasi Islam di dunia dan pada acara ini menyajikan bagaimana sejarah perjuangan mereka. Selain menampilkan gambaran film dan grafis, perjalanan Khalifah akan diperkuat oleh keterangan narasumber.

Dari uraian di atas dapat dipahami bahwa, setiap stasiun TV swasta dalam program dakwahnya menghadirkan ustaz atau ustazah yang memiliki spesifikasi topik yang menjadi ciri khasnya dalam menyampaikan ceramah. Contohnya: Mama Dedeh secara spesifik membahas topik permasalahan rumah tangga, Ustaz Yusuf Mansur membahas topik bersedekah, Ustaz Dhanu membahas topik keterkaitan penyakit dengan sifat buruk seseorang dan Ustaz Maulana yang memiliki ciri khas menyampaikan ceramah yang berkaitan dengan keseharian dan menggunakan bahasa yang ringan serta diselingi dengan humor.

Ketika dakwah muncul di media televisi maka akan memperhitungkan pendukung acara program dakwah, di antaranya: bintang tamu yang dihadirkan, susunan tata panggung, tema ceramah yang dihadirkan dan bahasa yang digunakan. Selain itu, pada saat ramadan, ceramah agama yang disiarkan di televisi juga diselipkan kuis berhadiah di dalamnya, bahkan bintang tamu yang dihadirkan adalah pelawak yang mengundang tawa penonton. Ceramah agama yang disajikan di televisi, kini seolah diharuskan untuk menghadirkan jamaah dari wilayah yang merupakan anggota 
pengajian, menyelingi dakwah dengan gaya khas dan sentuhan humor, dan berbagai hal yang menarik penonton, sehingga menarik minta penonton.

Ketika agama disajikan di televisi maka akan berkaitan erat dengan kepentingan media, yaitu: selera khalayak. Hal ini ditunjukan dengan bagaimana ceramah agama tidak hanya menampilkan pengetahuan mendalam mengenai agama dari ustaz yang membawakan, namun juga perlu disesuaikan dengan selera masyarakat yaitu; yang tidak membosankan, mengandung unsur humor dan dapat menghibur. Hal ini bertolak belakang dengan acara agama yang notabennya adalah acara yang seharusnya dikemas dengan penuh kewibawaan, Kekhusyukan dan merupakan hal yang tidak seharusnya disampaikan dan dipahami dengan gurauan. Kemasan ceramah dakwah di televisi kini ditujukan untuk menarik perhatian khalayak sebanyak mungkin karena dapat menikmati acara dakwah dengan lebih menyenangkan.

\section{Prinsip Kapitalisme dan Komodifikasi Agama melalui Tayangan Sinetron Religi}

Berdasarkan uraian tentang tampilan agama di media televisi di atas, maka yang sangat menarik untuk dicermati adalah fenomena sinetron religi. Sinetron religi merupakan salah satu bentuk tampilan agama di televisi yang banyak memikat masyarakakt. Namun jika ditinjau dari beberapa fakta empirik terkait tampilan agama di media seperti diungkap di atas bahwa, kapitalisme dan komodifikasi agama menjadi tolak ukur atas setiap tayangan yang ditampilkan oleh media televisi. Hal ini senada dengan apa yang diungkapkan oleh Koentowijoyo bahwa, keberadaan sinetron religius diberbagai stasiun televisi selama ini adalah hasil dari sinergi antara budaya mesjid dan budaya pasar. Meskipun dalam kenyataannnya dominasi pasar atas masjid lebih menonjol karena maraknya sinetron religius lebih banyak berangkat dari basik globalisasi dan semangat kapitalisme yang selalu berpijak dari trend industrialisasi untuk mendatangkan keuntungan daripada niat suci untuk berdakwah. ${ }^{4}$

\footnotetext{
hal. 131 .

${ }^{4}$ Koentowijoyo, Budaya dan Masyarakat, Edisi Paripurna (Yogyakarta : Tiara Wacana, 2006),
} 
Sampai detik ini keberadaan sinetron religi masih eksis di tengah-tengah masyarakat. Sinetron-sinetron religi biasanya mengangkat isu-isu agama Islam dalam setiap lakonnya. Hal ini memberikan kesan bahwa sinetron-sinetron tersebut memberikan pendidikan agama pada masyarakat. Namun, apabila dicermati lebih jauh tayangan-tayangan tersebut hanya memberikan imajinasi-imajinasi religius semata dan terkadang malah bertentangan dengan ajaran Islam yang sebenarnya.

Berdasarkan pengamatan diketahui bahwa, fenomena sinetron religi atau sinetron yang menggunakan simbol-simbol ajaran agama Islam telah mendominasi ruang-ruang pertelevisian di Indonesia. Bahkan fenomena sinetron religi semakin mendominasi layar kaca ketika menjelang bulan Ramadhan. Hal demikian tentu ada motif ekonomi dan komersialitas dibalik munculnya sinetron religi. Hal ini dapat dilihat di beberapa stasiun TV swasta seperti; RCTI, SCTV, ANTV, Global TV, MNC TV, INDOSIAR, TRANS TV, dan TRANS 7.

Menurut Amir Paliang bahwa, hampir semua sinetron komersial di Indonesia adalah sinetron yang ideologi ekonominya kapitalisme. Kapitalisme adalah sebuah sistem ekonomi yang tidak berlandaskan pada keyakinan apapun (Tuhan, sosial, kultural dan moral). Oleh karena itu, kapital bukanlah urusan Tuhan maupun menyangkut moral, melainkan bagaimana sistem kapital dengan berbagai caranya bisa mendapatkan keuntungan yang sebanyak-banyaknya. ${ }^{5}$ Begitu juga dengan konteks sinetron religi sekarang sepertinya berubah tema dalam menyajikan program sinetronnya, tetap dibalut dengan judul yang bernuansa keislaman akan tetapi isinya berbau masalah percintaan remaja.

Gejala komodifikasi Islam yang mewujud ke dalam sinetron religi tersebut, sebetulnya telah berlangsung di Indonesia secara lebih intens setidaknya dalam dasawarsa terakhir. Gejala ini bisa dilihat di beberapa stasiun televisi swasta, televisi swasta menggunakan kesempatan ini dengan sebaik-baiknya untuk menayangkan sinetron-sinetron yang bergenre religi. Setidaknya ada empat hal yang memotivasi

\footnotetext{
${ }^{5}$ Sujarwa, Mitos Dibalik Kisah-kisah Sinetron Dalam Perspektif Hegemoni dan Kapitalisasi, (Yogyakarta: Pustaka Pelajar, 2010), hal. 2
} 
| ARI WIBOWO| Komodifikasi Agama: Studi Analisis terhadap Tampilan Agama ...

hadirnya berbagai penggarapan tayangan sinetron yang semakin marak akhir-akhir ini. Pertama; animo masyarakat yang memang haus hiburan ringan, segar dan gampang dicerna. Kedua; banyaknya stasiun televisi swasta nasional maupun lokal lahir dan selanjutnya memberikan ruang seluas-luasnya untuk tayangan ini. Ketiga; meningkatnya para pengusaha (investor) yang tergiur dengan nilai ekonomis kesuksesan penggarapan sinetron dari pada film. Keempat: stok artis yang sangat banyak, terutama setelah maraknya ajang pencarian bakat, kontes, dan casting di berbagai acara. Kehadiran sinetron inilah wujud dari representasi realitas sosial. ${ }^{6}$

Dengan demikian dapat dipahami bahwa, diantara sekian banyak sinetron yang beredar masih banyak yang perlu dievaluasi ulang, terutama sinetron religi islami, paling tidak berkaitan dengan kualitas isi cerita dan teknis penggarapannya. Hadirnya sinetron religius islami memang sangat membanggakan, namun banyak dari sekian ragam senetron jenis ini, yang digarap secara asal, dan terutama substansi isi cerita, citra agama dan pesan yang disampaikannya.

Patut diketahui juga bahwa, fenomena sinetron disatu sisi merupakan pintu masuk bagi penyebaran nilai-nilai agama, di sisi lain ternyata tangan-tangan kapitalisme melalui Production House (Rumah Produksi) menggunakan kesempatan ini untuk memupuk keuntungan. Mereka tidak peduli benar atau salah pesan-pesan yang disampaikan, bahkan dampak dan pengaruh yang dibawa oleh sinetron tersebut, namun mereka lebih peduli terhadap besar kecilnya rating dalam sinetron tersebut dan bahkan mengkomoditaskan suatu kebudayaan yang sebetulnya bersifat positif. Ketika media swasta tumbuh sebagai sebuah korporasi bisnis yang menjanjkan, maka muncul asumsi bahwa mereka dibangun atas pondasi kapitalis yang kuat. Orientasi mereka hanya akan bemuara pada keuntungan atau revenue. Terbukti dari warna tayangan yang lebih

\footnotetext{
${ }^{6}$ Sajian acara televisi mengakomodasi praktik sosial, yang memproduksi representasi realitas sosial. Acara televisi mampu memproduksi representasi realitas sosial dan melibatkan interaksi dan negosiasi yang kompleks dan dinamis dari sejumlah pelaku. Interaksi dan negosiasi itu, bekerja melalui tiga tahap, yakni, tahap pra-penayangan, penayangan, maupun pasca-penayangan. Lihat Graeme Burton, Talking Television: An Intoduction to The Study of Talk Television. (London: Hodder Arnold, 1991), hal. 128-129. Dikutip juga oleh Muhammad Zamron dalam artikelnya Potret Dakwah Kontroversial Tayangan Televisi. Lihat Muhammad Zamroni, "Potret Dakwah Kontroversial Tayangan Televisi" Jurnal APLIKASIA, vol.16, no.1 (2016).
} 
dominan hiburan daripada informasi dan edukasi. Apapun akan dilakukan media sejauh dapat menghasilkan keuntungan walaupun harus dengan biaya yang besar.

Begitu juga halnya dengan motif ekonomi yang begitu kuat dalam bisnis media, menjadikan bisnis media padat kompetisi. Masing-masing media berlomba dalam mengatur strategi dan langkah jitu untuk tetap bertahan dan berkembang. Seperti apa yang diungkapkan oleh Gillian Doyle bahwa ada tiga langkah strategi bisnis media (ekspansi) yang lazim dilakukan, yaitu; Vertical, Horizontal, dan Diagonal Expansion. Vertical Expansion adalah sebuah langkah media untuk bisa meraih keuntungan dengan melakukan penguatan jaringan dari hulu ke hilir, mulai dari produksi sampai pada tahapan konsumsi. Sehingga keuntungan yang dimungkinkan adalah tidak ada yang hilang dari setiap tahapan yang dilakuan (production, packaging, and distribution). Salah satu bentuk ekspansi vertikal yang dilakukan media adalah memproduksi tayangan dakwah dan agama dengan sentuhan kreatif dan hiburan, serta memastikan bahwa acara ini akan diterima dengan baik oleh audiens. Adapun Horizontal Expansion adalah bagaimana langkah media untuk memperbesar keuntungan mereka dengan melakukan ekspansi terhadap unit bisnis yang sama, misal akuisisi, merger, dan kerjasama dengan media lain. Sedangkan strategi bisnis ketiga yang saat ini banyak diminati adalah Diagonal Expansion, dimana media memutuskan untuk melakukan pengayaan pada institusi media mereka dengan cara apapun yang dipandang tepat, walaupun tidak in line dengan bisnis yang dijalankan. Seperti bekerjasama dengan provider telekomunikasi, dan partai politik, tujuannya adalah memperkaya media mereka dari sisi finansial. ${ }^{7}$

Maka berdasarkan hal tersebut dapat dipahami bahwa, dalam konteks tayangan dakwah dan agama, media melakukan ekspansi vertikal. Media mencari nilai unik dan daya tarik tayangan yang disajikan, langkah ini dari sisi biaya jauh lebih kecil jika dibanding dengan langkah akuisisi media lain yang ongkosnya pun jauh lebih besar. Dari sisi resiko, mengemas tayangan agama dan dakwah lebih tidak beresiko dalam sisi bisnis, sebab jika tayangan yang disajikan dirasa tidak menguntungkan akan dengan

${ }^{7}$ Gillian Doyle, Understanding Media Eonomics, (London : Sage Publications, 2002), hal. 57 
mudah dihentikan atau dimodifikasi. Inilah yang menyebabkan kenapa tayangan agama di televisi konten (isi) tayangannya tidak netral dan secara substantif jauh dari kemurnian ajaran Islam yang sesungguhnya. Hal tersebut karena tayangan agama di televisi telah dibumbui dengan berbagai pernak-pernik hiburan dan konten komersil.

\section{Optimalisasi Strategi Dakwah dalam Menghadapi Kapitalisme Media Televisi}

Di era informasi pada saat ini dakwah dan media televisi tidak bisa dipisahkan, media telah menjadi alat bantu yang paling efektif dan efisien dalam menyebarluaskan ajaran Islam kepada masyarakat. Namun secara kontradiktif juga telah menjadi alat yang dapat merusak sendi-sendi ajaran Islam, jika media tersebut hanya dijadikan sebagai lahan komersil yang banyak menghasilkan keuntungan materi. Oleh karena itu, perlunya optimalisasi strategi dakwah untuk membendung usaha kapitalis dalam mengkomodikasikan ajaran agama.

Ada beberapa hal yang menurut pemahaman penulis perlu dicermati sebagai upaya membendung usaha kapitalis dalam mengkomodikasikan agama, di antaranya sebagai berikut:

1. Meningkatkan pendekatan personal antara subjek dakwah dengan penguasa media.

Pendekatan personal (Manhaj As-Sirri) adalah pendekatan dakwah yang terjadi secara langsung dan individual antara subjek dakwah dengan objek dakwah. ${ }^{8}$ Dalam hal ini hubungan kemitraan antara subjek dakwah dengan penguasa media atau house Production yang langsung bertatap muka, sehingga seorang da'i dapat menyampaikan pesan-pesan dakwahnya kepada si pemilik media. Proses pendekatan personal ini dapat dimanfaatkan oleh da'i untuk mengarahkan pemilik media agar bisa memproduksi tayangan agama sesuai dengan ajaran Islam. Diharapkan pula tayangan agama di televisi dapat dikemas dengan baik dan benar sehingga memberi keuntungan bagi dunia dakwah maupun dunia pertelevisian. Jika biasanya da'i yang diarahkan oleh media namun dengan pendekatan ini da'i bisa mengarahkan media.

\footnotetext{
124

${ }^{8}$ Ali Musthafa Yakub, Sejarah Dan Metode Dakwah Nabi, (Jakarta: Pustaka Firdaus, 1997), hal.
} 
2. Meningkatkan pendekatan struktural.

Pendekatan struktural yaitu pengembangan dakwah dapat melalui jalur struktural formal misalnya melalui pemerintahan. Hal ini yang pernah ditempuh oleh Prof. Dr. H. Amien Rais, dengan Ikatan Cendikiawan Muslim Indonesia (ICMI). ${ }^{9}$ Pendekatan ini bisa dilakukan oleh para subjek dakwah yang tergabung ke dalam beberapa organisasi dakwah atau organisasi kemasyarakatan untuk memberi rekomendasi kepada pemerintah terkait perlunya peningkatan regulasi, kebijakan, dan pengawasan terhadap penyiaran di Indonesia, contohnya: Majelis Ulama Indonesia (MUI), Dewan Masjid Indonesia (DMI), Nahdhatul Ulama, Muhammadiyah dan lain sebagainya, bisa menggunakan kekuatannya untuk menjadi agent of control terhadap tayangan agama di media televisi.

Ada dua jenis regulasi dan kebijakan yang dapat dilakukan oleh pemerintah, yaitu regulasi tayangan dan kebijakan pendidikan, dalam hal ini yang terkait adalah Kementerian Agama. Kementerian Agama dapat dengan tegas memberikan peringatan kepada stasiun televisi yang dipandang menyalahi norma agama. Ujungnya adalah himbauan dan rekomendasi kepada masyarakat selaku audiens terhadap acara tertentu. Dengan demikian regulasi dan kebijakan Kementerian Agama secara tidak langsung juga menjadi kontrol dalam setiap tayangan media televisi. Kebijakan selanjutnya adalah terkait dengan pendidikan media di lingkungan Kementerian Agama.

Kebijakan pendidikan ini menjadi penting sebab terpaan media. yang berkelanjutan akan berdampak pada sikap dan perilaku konsumen media. Akan tetapi akan berbeda jika setiap jenjang pendidikan mendapat pemahaman media dengan tepat sesuai dengan jenjang pendidikannya, mulai dari pendidikan dasar, menengah, menengah atas, bahkan sampai pendidikan tinggi. Setidaknya beberapa pertanyaan dasar terkait dengan media dapat dipahamai, seperti : siapa pemilik media?, bagaimana sebuah

${ }^{9}$ Samsul Munir Amin, Rekonstruksi Pemikiran Dakwah Islam, (Jakarta: AMZAH, 2008), hal. 
tayangan diproduksi?, apa ideologi dan orientasi tayangan media yang disajikan? Dan lain sebagainya. ${ }^{10}$

3. Peningkatan usaha organisasi dakwah untuk membangun media.

Media adalah sarana untuk mengeluarkan pesan-pesan yang disampaikan oleh da'i kepada mad'u. Salah satu metode yang dinilai efektif untuk membendung kapitalisme media adalah dengan juga membangun media televisi. Namun untuk membangun atau mendirikan media televisi berbasis dakwah tentu membutuhkan finansial yang sangat besar. Oleh karena itu, inilah pentingnya organisasi keagamaan seperti MUI untuk membuat statsiun TV yang khusus menyiarkan ajaran-ajaran Islam yang benar bagi masyarakat, sehingga media ini bisa menjadi penyeimbang terhadap tayangan televisi swasta.

Meskipun tidak berada pada jenis media yang sama, media balancing juga dapat dilakukan melalui media yang lain seperti radio, surat kabar, dan online media. Diharapkan, semakin banyak pilihan media yang ditawarkan, semakin banyak ragam informai yang diberikan, sehingga masyarakat tidak hanya bergantung pada satu sumber informasi saja, melainkan banyak media alternatif yang digunakan. Jika salah satu media dirasa kurang tepat dalam menyajikan tayangan, maka dapat dilengkapi oleh media yang lain.

4. Peningkatan metode dakwah fardhiyah.

Untuk menjawab tantangan kapitalisme media, maka perlu dikembangkan metode dakwah fardhiyah, yaitu metode dakwah yang menjadikan pribadi dan keluarga sebagai sendi utama dalam aktivitas dakwah. Dalam usaha membentuk masyarakat yang dicirikan oleh Islam harus berawal dari pembinaan pribadi dan keluarga yang Islami, sebab lingkungan keluarga merupakan elemen sosial yang amat strategis dan memberi corak paling dominan bagi pengembangan masyarakat secara luas.

Menurut Moehammad Noer bahwa, pembinaan pribadi dan keluarga yang Islami ini dapat ditempuh melalui dua cara, yaitu: pertama, peningkatan fungsi orang tua (ibu

\footnotetext{
${ }^{10}$ Andrew Burn and James Durran, Media Literacy in School: Practice, Production and Progression, (London: Paul Chapman Publishing, 2007), hal. 83
} 
dan bapak) sebagai tauladan dalam rumah tangga; kedua, perlunya dibentuk lembaga Konsultan Keluarga Sakinah (KKS) dan Klinik Rohani Islam (KRI) dalam setiap komunitas muslim. Untuk pelaksanaan KKS dan KRI ini diperlukan tenaga penyuluh dan konselor Islam yang handal baik secara teoritis maupun secara praktis. ${ }^{11}$

Di sinilah peran lembaga dakwah untuk membina dan mendorong agar anggotanya mengembangkan dakwah fardiyah sehingga masing-masing keluarga dapat terpantau dan terkendali, sekaligus menjadi benteng terhadap beberapa tampilan agama di televisi yang bernuansa kapitalis.

5. Meningkatkan profesionalitas dan objektifitas subjek dakwah

Da'i haruslah professional dan cermat serta dapat bersikap bijak dalam menggunakan metode, materi maupun media agar mengenai sasaran. Dakwah pada masa sekarang dengan masa Rasululullah Saw. jelaslah tidak sama, karena beda ruang dan waktu. Kembalikan dakwah pada hakikatnya, jalan mencapai popularitas tidaklah tepat jika menggunakan dakwah sebagai alatnya, karena dakwah adalah salah satu bentuk kecintaan kita pada Tuhan, ibadah bukan perfilman ataupun sandiwara yang menampilkan realitas konstruktif, melainkan ajaran amar ma'ruf nahi munkar. Pop dalam budaya pop sesungguhnya berarti bahwa impuls-impuls dan citra budaya berasal dari lingkungan sehari-hari dan kemudian diperhatikan, diinterpretasikan, dikomoditaskan, dan diedarkan oleh industri-industri kebudayaan dan media massa. Hal ini juga membutuhkan kecakapan seorang subjek dakwah dalam mengaplikasikan metode dakwah yang tepat. Sesuai dengan firman Allah Swt dalam surat an-Nahl ayat yang artinya: Serulah (manusia) kepada jalan Tuhan-mu dengan hikmah dan pelajaran yang baik dan bantahlah mereka dengan cara yang baik. Sesungguhnya Tuhanmu Dialah yang lebih mengetahui tentang siapa yang tersesat dari jalan-Nya dan Dialah yang lebih mengetahui orang-orang yang mendapat petunjuk. $^{12}$

\footnotetext{
${ }^{11}$ Mohammad Noer, “Dakwah untuk Umat,” Makalah dalam Workshop Program Studi Sejenis Ditjen Pendidikan Islam Depag RI, 2007, hal. 5

${ }^{12}$ Kementerian Agama RI, Al-Qur'an dan Terjemahannya, (Bandung: Fokusmedia, 2011), hal. 
| ARI WIBOWO| Komodifikasi Agama: Studi Analisis terhadap Tampilan Agama ...

\section{E. Kesimpulan dan Saran}

Tayangan dakwah dan agama menjadi salah satu komoditi yang bisa diandalkan. Terlihat dari porsi yang diberikan untuk plotting acara keagamaan dalam setiap harinya. Setiap pagi stasiun televisi memiliki program acara keagamaan yang disajikan dalam bentuk ceramah agama. Semakin lama, batasan antara dakwah dan bisnis menjadi sangat tipis. Dikhawatirkan, motif ekonomi dan bisnis lebih dominan daripada dakwah dan agama. Batasan ini menjadi semakin tipis ketika kemasan dakwah dibuat dengan gaya hiburan dan lebih banyak guyonan. Ditambah para da'i menjadi selebriti dadakan dengan menejadi sasaran empuk infotainment.

Ada dua sisi perbaikan yang dimungkinkan, pertama dari sisi media, tentu ini sulit dan berat, sebab orientasi materi adalah khas dari media swasta yang bergantung hidup dari iklan. Tetapi tidak mustahil untuk dilakukan, sebab bagaimanapun ada juga media yang mengemas acara dakwah dengan baik. Kedua, dari sisi konsumen, perubahan pada sisi inilah yang paling dimungkinkan, yaitu bagaimana memberikan pencerahan pada masyarakat perilaku mengkonsumsi media dengan bijak. Diharapkan, dengan optimalisasi strategi dakwah dalam membendung kapitalisme media membuat kearifan masyarakat dalam mengkonsumsi media (media literacy) menjadi lebih baik dan bijak.

\section{Saran}

Bagi produser hendaklah memproduksi sebuah sinetron bertema religi lebih netral dan tidak berpihak kepada suatu keuntungan dan kepentingan disatu pihak saja. Sinetron merupakan sebuah gambaran realitas yang ada ditengah masyarakat, sebaiknya bagi produser bisa menggambarkan secara realitas dan jujur setiap adegan yang ditampilkan di dalam sinetron tanpa harus memasukan suatu propaganda atau maknamakna yang terselubung yang tujuannya hanya untuk mendukung salah satu pihak, karena sinetron fungsinya sebagai media informasi dan media pembelajaran bagi masyarakat banyak. 
Bagi seniman perfilman hendaknya dalam membuat sinetron yang bergenre religi diharapkan mempunyai visi, misi dan dakwah pada lembaga yang dijadikan latar belakang pembuatan suatu karya seni sinetron, karena sinetron tidak hanya memberi tontonan tapi juga memberi tuntunan. Hendaknya sutradara memfokuskan tayangan yang menjadi kebutuhan dan lebih bermanfaat bagi masyarakat, karena karakter suatu bangsa bisa dinilai dari tayangan-tayangan di media yang ada.

Bagi masyarakat luas hendaknya agar lebih cermat dalam memahami makna yang ada dalam sebuah sinetron, agar nantinya dapat memahami pesan yang positif dari sinetron tersebut, maka dari itu diharapkan masyarakat lebih memilah dan memilih lagi mana tayangan yang bermanfaat dan mana tayangan yang kurang bermanfaat. Jadilah penikmat media yang kritis dan cerdas, juga tidak hanya jadi pemirsa atas suatu kejadian. Namun, jadilah bagian dari itu, baik bagian dari media atau apapun. Kritis dan cerdaslah dalam menerima informasi. Bagi para da'i hendaklah professional dan objektiv dalam melaksanakan dakwah di media. Para da'i diharapkan tidak terjerumus dalam kapitalisme media, justru seharusnya para da'i mampu untuk memberi penawaran yang realistis serta objektif tentang dakwah yang sebenarnya. 
| ARI WIBOWO | Komodifikasi Agama: Studi Analisis terhadap Tampilan Agama ...

\section{Daftar Pustaka}

Amin, Samsul Munir. (2008). Rekonstruksi Pemikiran Dakwah Islam, Jakarta: AMZAH.

Burton, Graeme. (1991). Talking Television: An Intoduction to The Study of Talk Television. London: Hodder Arnold.

Burn, Andrew and James Durran. (2007). Media Literacy in School: Practice, Production and Progression. London: Paul Chapman Publishing.

Doyle, Gillian. (2002). Understanding Media Eonomics. London : Sage Publications.

Effendy, Onong Uchjana. (2002). Ilmu, Teori, dan Falsafah Komunikasi. Bandung : Cipta Aditya Bakti.

Kementerian Agama RI. (2011). Al-Qur'an dan Terjemahannya. Bandung: Fokusmedia.

Koentowijoyo. (2006). Budaya dan Masyarakat, Edisi Paripurna. Yogyakarta: Tiara Wacana.

Morley, David. (1992). Television, Audiences and Cultural Studies. New York: Routlegde.

Noer, Mohammad. (2007). "Dakwah untuk Umat," Makalah dalam Workshop Program Studi Sejenis Ditjen Pendidikan Islam Depag RI.

Sireger, Ashadi. (2001). Menyingkap Media Penyiaran: Membaca Televisi Melihat Radio. Yogyakarta : LP3Y.

Sujarwa. (2010). Mitos Dibalik Kisah-kisah Sinetron Dalam Perspektif Hegemoni dan Kapitalisasi. Yogyakarta: Pustaka Pelajar.

Yakub, Ali Musthafa. (1997). Sejarah Dan Metode Dakwah Nabi. Jakarta: Pustaka Firdaus. 